\title{
Levels of mannose-binding lectin in individuals with visceral leishmaniasis in the northeast region of Brazil
}

E.L. da Silva', M. Campos Júnior ${ }^{2}$, S.G. Monteiro³, G.C. Costa ${ }^{4}$, A.L.P. Magalhães ${ }^{5}$, M.D.C. Santos ${ }^{6}$, A.J.M. Caldas ${ }^{1}$ and M.M.G. Pimentel

'Departamento de Enfermagem, Universidade Federal do Maranhão, São Luís, MA, Brasil

${ }^{2}$ Laboratório de Genética Humana, Instituto Oswaldo Cruz, Fiocruz, Rio de Janeiro, RJ, Brasil

${ }^{3}$ Programa de Pós-Graduação em Biologia Parasitária, Universidade Ceuma, São Luís, MA, Brasil

${ }^{4}$ Departamento de Patologia, Universidade Federal do Maranhão, São Luís, MA, Brasil

${ }^{5}$ Grupo de Estudos e Pesquisas em Administração e Gerência do Cuidado em Enfermagem e Saúde, Departamento de Enfermagem,

Universidade Federal de Santa Catarina, Florianópolis, SC, Brasil

${ }^{6}$ Centro de Pesquisa Clínica, Hospital Universitário da Universidade Federal do

Maranhão, São Luís, MA, Brasil

${ }^{7}$ Laboratório de Genética Humana, Departamento de Genética,

Universidade Estadual do Rio de Janeiro, Rio de Janeiro, RJ, Brasil

Corresponding author: E.L. da Silva

E-mail: elza.lima@terra.com.br

Genet. Mol. Res. 14 (4): 19094-19101 (2015)

Received June 24, 2015

Accepted September 11, 2015

Published December 29, 2015

DOI http://dx.doi.org/10.4238/2015.December.29.18

ABSTRACT. Visceral leishmaniasis $(\mathrm{VL})$ is one of the seven priority endemic diseases in the world. The clinical outcome of many infections is not only dependent on the pathogenic organism, but also on the genetic variability of the host susceptibility to infection. Mannose-binding lectin (MBL) is a 
protein that plays an important role in the innate immune system. The aim of this study was to compare the serum levels of MBL between healthy controls and carriers of $\mathrm{VL}$. The $\mathrm{VL}$ cases were recruited randomly from the main hospitals and referral outpatient clinics for VL in São Luís, and from home visits. Determination of MBL protein levels was performed by enzyme-linked immunosorbent assay. Of the 161 patients with VL and the 161 healthy controls, 60.9 and $67.1 \%$ had high levels of $M B L$, respectively. There was no significant difference in MBL levels between cases and controls. Low socioeconomic status and living conditions are conducive to the occurrence of VL. Owing to the small number of existing studies, it is extremely important to conduct further studies on MBL levels and susceptibility to $V L$, especially in regions where the disease is endemic, such as Maranhão, Brazil.

Key words: Visceral leishmaniasis; Mannose-biding lectin; Serum concentration

\section{INTRODUCTION}

Visceral leishmaniasis (VL), also known as kala-azar, is an important public health problem and is considered to be one of the world's seven priority endemic diseases. It is a chronic, severe, and highly lethal disease when ignored or inadequately treated (WHO, 2009).

The host inability to developan effective immune response to Leishmania infection is associated with several aspects of cellular immunity such as differentiation of lymphocytes, antigen presentation, cytokine production, and the activation mechanisms of macrophage lysis (Ghalibet al., 1993; Karp et al., 1993). Thus, one of the main characteristics of innate immune response deficiency is the interaction between the molecular patterns associated with the pathogen and receptors present on host cells known as pattern recognition receptors (PRR). Some PRRs, such as the mannose-binding lectin (MBL) protein, play an important role in innate immunity (Turner, 2003).

MBL plays an important role in the first line of host defense against pathogens (Super et al., 1989; Turner, 2003). It is a serum protein that belongs to the collecting family; it is mainly synthesized in the liver by hepatocytes and is released into the blood stream (Ezekowitz, 1998). However, research conducted on mice has shown that MBL can also be synthesized by other organs such as the heart, brain, and kidneys (Dumestre-Perard et al., 2002). Furthermore, this protein has the ability to recognize and bind to carbohydrates on the surface of a wide variety of microorganisms such as Gram-positive and Gram-negative bacteria, viruses, fungi, and protozoa (Fraser et al., 1998; Worthley et al., 2005).

The association between MBL and human diseases has been investigated in recent years because of the increasing evidence that correlates genetic variation and susceptibility to some types of infections and autoimmune, metabolic, and cardiovascular diseases (Rector et al., 2001; Roy et al., 2002; Seibold et al., 2004; Fidler et al., 2004; Eisen et al., 2006; Garred et al., 2006; Eisen et al., 2008).

MBL deficiency in human serum has been associated with increased susceptibility to several infections (Lau et al., 1996; Garred et al., 1997; Summerfield et al., 1997; Davies et al.,1997; Graudal et al., 1998; Koch et al., 2001). Infection by VL may be influenced directly by the level of MBL. Furthermore, phagocytosis of promastigotes opsonized with this protein induces the secretion of a higher concentration of TNF- $\alpha$ and IL- 6 by human monocytes, demonstrating that MBL may modulate the clinical course and the function of infected monocytes (Santos et al., 2001). 
Thus, the present study evaluated these rum levels of MBL protein in individuals with VL and in healthy controls in the regions of São Luís, Maranhão, Brazil, where the disease is endemic.

\section{MATERIAL AND METHODS}

We performed an analytical, cross-sectional study between January 2010 and December 2012 on 322 individuals who lived in regions of São Luís, Maranhão, where VL was endemic.

\section{Sample}

The sample comprised a group of 161 unrelated individuals of both genders (1-50 years of age, $5.1 \pm 7.6$ ) with VL (cases), and 161 unrelated healthy subjects of both genders (1-74 years of age, $29.1 \pm 13.5$ ) who were not infected by Leishmania sp and lived in the same geographic region as the cases (controls). The VL cases were recruited randomly from the main hospitals and referral outpatient clinics for VL in São Luís, and from home visits by searching the records of the National Health Foundation (FUNASA).

The individuals were classified according to the presence or absence of clinical forms as follows: (a) healthy/control/not infected-individuals who had no clinical manifestations of VL and who were negative to anti-Leishmania antibodies according to an enzyme-linked immunosorbent assay (ELISA); and (b) VL-symptomatic individuals (sick)-individuals who showed a clinical-laboratory profile of the disease (Brasil, 2009), and who were positive for a parasitological bone marrow aspirate examination for Leishmania sp amastigotes forms.

\section{Quantification of MBL serum levels}

Data collection was performed using a questionnaire that identified individuals, epidemiological data, clinical characteristics, and medical examinations. Peripheral blood $(5 \mu \mathrm{L})$ was used for quantification of MBL serum levels by ELISA (MBL Oligomer ELISA Kit, Copenhagen S, Dinamarca), according to the manufacturer instructions. Levels of $\mathrm{MBL}$ above $1000 \mathrm{ng} / \mathrm{mL}$ were considered high, $100-1000 \mathrm{ng} / \mathrm{mL}$ were considered intermediate, and under $100 \mathrm{ng} / \mathrm{mL}$ were considered deficient or low.

\section{Statistical analysis}

Data were analyzed using the SPSS software for Windows 17.0 (2007). To evaluate the effects of group and gender on MBL variables we used the nonparametric Mann-Whitney test. A Spearman correlation was performed todetermine if $\mathrm{MBL}$ levelwas relatedto age. Results were considered statistically significant when the $P$ value was not more than $5 \%(P \leq 0.05)$.

\section{Ethics}

All participating individuals freely provided written informed consent before the collection of samples. The research was approved by the Research Ethics Committee of the University Hospital, Federal University of Maranhão-CEP-HUFMA, with protocol number 005613/2009-80. 


\section{RESULTS}

Of the VL cases that participated in this study, 50.3\% were female and under 10 years of age (89.4\%). Concerning extent of education, $14.3 \%$ had studied for less than 8 years. In reference to the monthly income and residence, $47.2 \%$ received less than one minimum wage and $56.52 \%$ lived in houses made of brick (Table 1).

Table 1. Social demographic characteristics of visceral leishmaniasis (VL) cases and healthy controls.

\begin{tabular}{|c|c|c|c|c|}
\hline & \multicolumn{2}{|c|}{ Cases } & \multicolumn{2}{|c|}{ Controls } \\
\hline & $\mathrm{N}$ & $\%$ & $\mathrm{~N}$ & $\%$ \\
\hline \multicolumn{5}{|l|}{ Gender } \\
\hline Female & 81 & 50.3 & 130 & 80.7 \\
\hline Male & 80 & 49.7 & 31 & 19.3 \\
\hline \multicolumn{5}{|l|}{ Age group (years) } \\
\hline$<10$ & 144 & 89.4 & 6 & 3.7 \\
\hline $11-20$ & 8 & 5.0 & 27 & 16.8 \\
\hline $21-30$ & 6 & 3.8 & 81 & 50.3 \\
\hline $31-40$ & 1 & 0.6 & 24 & 14.9 \\
\hline$>40$ & 2 & 1.2 & 23 & 14.3 \\
\hline \multicolumn{5}{|c|}{ Education level (years) } \\
\hline No education & 3 & 1.9 & 5 & 3.1 \\
\hline$\leq 8$ & 23 & 14.3 & 50 & 31.0 \\
\hline$\geq 8$ & 16 & 10.0 & 101 & 62.7 \\
\hline Not applicable & 127 & 78.9 & 5 & 3.1 \\
\hline \multicolumn{5}{|c|}{ Family income (minimum age) } \\
\hline$<1$ & 76 & 47.2 & 38 & 23.6 \\
\hline $1-2$ & 67 & 41.6 & 59 & 36.6 \\
\hline $2-4$ & 16 & 9.9 & 40 & 24.8 \\
\hline$>4$ & - & - & 21 & 13.0 \\
\hline Does not know & 2 & 1.2 & 3 & 2.0 \\
\hline \multicolumn{5}{|l|}{ Dwelling type } \\
\hline Brick & 91 & 56.52 & 142 & 88.20 \\
\hline Thatch & 12 & 7.45 & 1 & 0.62 \\
\hline Wood & 47 & 29.20 & 16 & 9.93 \\
\hline Adobe & 7 & 4.35 & - & - \\
\hline Others & 4 & 2.48 & 2 & 1.25 \\
\hline Total & 161 & 100 & 161 & 100 \\
\hline
\end{tabular}

Among the 161 unrelated individuals with VL, 107 were hospitalized and 54 had a history of VL.Of the 107 hospitalized individuals, 65 had high levels of MBL, 36 had low levels, and there were six with intermediate levels of serum MBL. Concerning those with a history of $\mathrm{VL}, 33$ had high levels of MBL, 18 had low levels, and there were three with intermediate MBL serum levels (Figure 1).

There was no statistically significant difference in the serum levels of MBL among the carriers of VLand the controls $(P=0.423)$ andno relation to gender was found $(P=0.326)$. There was no difference regarding age $(P=0.304)$ (Table 2). No significant correlation was found between the age of the individual and the level of $\mathrm{MBL}(r=0.009 ; \mathrm{P}=0.876)$. 


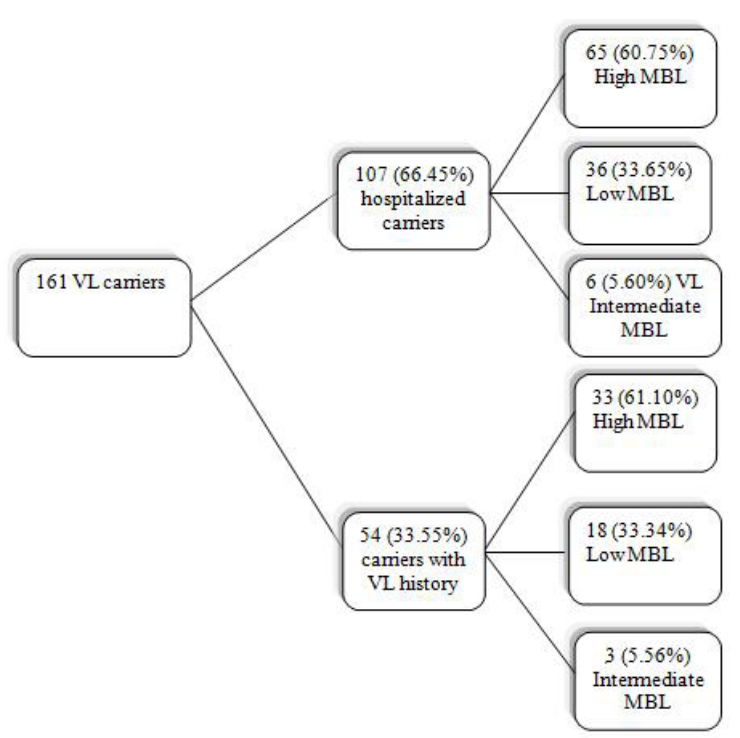

Figure 1. Distribution of individuals with visceral leishmaniasis $(\mathrm{VL})$ and serum levels of mannose-binding lectin (MBL).

Table 2. Comparison of the levels of mannose-biding lectin (MBL) between groups and between genders using the Mann-Whitney test. Subjects were recruited from São Luís, Maranhão, between January 2010 and December 2012.

\begin{tabular}{llll}
\hline Variable & $\mathrm{N}$ & $\mathrm{MBL}(\mathrm{ng} / \mathrm{mL})$ & P value \\
\cline { 3 - 3 } & & Mean $\pm \mathrm{SD}$ & \\
\hline Group & 161 & $18174.1 \pm 14099.3$ & 0.423 \\
$\quad$ Controls & 161 & $31884.8 \pm 17192.5$ & \\
$\quad$ Carriers of VL & 111 & $38139.0 \pm 206792.9$ & 0.326 \\
$\quad$ Male & 211 & $18133.0 \pm 14336.2$ & \\
$\quad$ Female & & & \\
\hline
\end{tabular}

$\mathrm{VL}=$ visceral leishmaniasis.

\section{DISCUSSION}

To the best of our knowledge, this is the first study to investigate the levels of MBL protein in individuals with $\mathrm{VL}$ in comparison with healthy controlsin regions where the disease is endemic in São Luís, Maranhão, Brazil.

In carriers of VL, no statistically significant difference was found in the level of MBL between genders in our study. However, other studies have shown differences in the level of MBL between genders in those infected with VL. After puberty, teenagers and adult males are among the most affected by VL owing to hormonal fluctuations that may influence susceptibility to the disease (Jeronimo et al., 2007; Nylén et al., 2007).

However, about $90 \%$ of cases occur in individuals of less than 10 years of age. Studies have shown that children are more affected by VL than adults, and those under 5 years of age are most susceptible to the disease (Badaró et al.,1986; Maia-Elkhoury et al., 2008; Brasil, 2009), possibly owing to the high rates of nutritional deficiency and the consequent low resistance to disease 
in Maranhão, which is considered one of the poorest states in Brazil (IBGE, 2007).

In this study, we noticed the low socioeconomic status among the individuals with VL. According to Nascimento et al. (1996), the ideal environment for VL establishment is mainly low socio economic status, affecting human settlements that live in poor housing conditions.

There was no statistically significant difference in the serum levels of $M B L$ among the carriers of $\mathrm{VL}$ and the controls $(P=0.423)$. MBL deficiency (serum concentration below $100 \mathrm{ng} / \mathrm{mL}$ ) is associated with severity and susceptibility to infectious diseases (Eisen et al., 2006). However, high MBL concentrations may favor infection by some intracellular parasites such as Leishmania, which uses C3 opsonization and its receptor to enter the host cells (Garred et al.,1994).Thus, mechanisms that decrease complement activation may hinder the entry of the parasites into the cells (Santosetal., 2001; Bonar et al., 2004).

The importance of MBL protein in innate immunity has been shown by studies that associate deficiency of MBL with susceptibility to several infectious diseases, mainly extracellular pathogens, and particularly the microorganisms that cause acute infection in childhood (Garred et al.,1995; Garred et al., 1997; Koch et al., 2001; Eisen et al., 2006). Conversely, some evidence suggests that there is a direct association between MBL levels and the risk of infection by some intracellular parasites such as Leishmania, although as yet there is no scientific consensus. This is mainly owing to the lack of studies that have sought to elucidate the relationship between MBL and VL.

A study in the northeast region of Brazil found that serum levels of MBL protein are significantly associated with the risk of developing $V L$ within the limits of opsonization higher than 500 $\mathrm{ng} / \mathrm{mL}$ (Alonso, 2007). The same study also showed that low levels of MBL protein may protect against the progression of VL infection. The author emphasized that in areas of high transmission of the disease there must be epidemiological interventions along with clinical care. Furthermore, the author agreed with the concept that MBL is a "double-edged sword" and that intermediate levels of this protein may be the most desirable phenotype for innate protection against a variety of pathogens (Alonso, 2007). Santos et al. (2001) likewise reported that MBL levels are significantly higherin individuals with VL history than in asymptomatic infected VL individuals. Hamdi et al. (2013) also showed that MBL deficiency decreases the risk of developing VL.

It is noteworthy that of the $161 \mathrm{VL}$ patients evaluated, $107(66.45 \%)$ were admitted with clinical complications. Of these, $65(60.75 \%)$ had high serum level sof MBL protein, 36 (33.65\%) had low levels, and $6(5.60 \%)$ had intermediate levels. The remaining 54 individuals were those with a history of VL: $33(61.10 \%)$ with high serum levels of MBL, 18 (33.34\%) with low levels, and $3(5.56 \%)$ with intermediate levels. Alonso (2007) reported that high levels of MBL are more frequent among subjects with VL than among asymptomatic infected individuals, and are even more frequent among patients with clinical complications.

Owing to the lack of studies, more research into MBL and susceptibility to VL in endemic regions is necessary in order to increase our knowledge of the infection dynamics of this important public health problem.

\section{Conflicts of interest}

The authors declare no conflict of interest.

\section{ACKNOWLEDGMENTS}

The authors thank FAPEMA for its financial support. The authors also thank the Labora- 
tory of Immuno-Physiologyatthe Federal University of Maranhão, the Center of Clinical Research (CEPEC) at the University Hospital of the Federal University of Maranhão, the Laboratory of Genetic Studies and Histocompatibility $(\mathrm{LEGH})$ at the University Hospital of the Federal University of Maranhão, and the Laboratory of Mycology at the University Center of Maranhão.

\section{REFERENCES}

Alonso DP (2007). Mutações no gene que codifica a lectina ligante da manose e suas relações com a infecção por Leishmaniachagasi. Dissertação de Mestrado, Universidade Estadual Paulista "Júlio de Mesquita Filho", Instituto de Biociências, Campus de Botucatu, 89.

Badaró R, Jones TC, Lorenço R, Cerf BJ, et al. (1986). A prospective study of visceral leishmaniasis in an endemic area of Brazil. J. Infect. Dis. 154: 639-649.

Bonar A, Chmiela M and Rózalska B (2004). Level of mannose-binding lectin (MBL) in patients with tuberculosis. Pneumonol. Alergol. Pol. 72: 201-205.

Brasil (2009). System Disorders Notification Information - SINAN. Portal da Saúde [Internet] [cited on Nov 8, 2009]. Available at [http://dtr2004.saude.gov.br/sinanweb/novo/]. Accessed August 15, 2015.

Davies EJ, Teh LS, Ordi-Ros J, Snowden N, et al. (1997). A dysfunctional allele of the mannose binding protein gene associates with systemic lupus erythematosus in a Spanish population. J. Rheumatol. 24: 485-488.

Dumestre-Perard C, Ponard D, Arlaud GJ, Monnier N (2002). Evaluation and clinical interest of mannan binding lectin function in human plasma. Mol. Immunol. 39: 465-473.

Eisen DP, Dean MM, Thomas P, Marshall P, et al. (2006). Low mannose-binding lectin function is associated with sepsis in adult patients. FEMS Immunol. Med. Microbiol. 48: 274-282.

Ezekowitz RA(1998). Genetic heterogeneity of mannose-binding proteins: the Jekyll and Hyde of innate immunity? Am. J. Hum. Genet. 62: 6-9.

Fidler KJ, Wilson P, Davies JC, Turner MW, et al. (2004). Increased incidence and severity of the systemic inflammatory response syndrome in patients deficient in mannose-binding lectin. Int. Care Med. 30: 1438-1445.

Fraser IP, Koziel H and Ezekowitz RA (1998). The serum mannose-binding protein and the macrophage mannose receptor are pattern recognition molecules that link innate and adaptive immunity. Semin. Immunol. 10: 363-372.

Garred P, Madsen HO, Hofmann B and Svejgaard A (1995). Increased frequency of homozygosity of abnormal mannanbinding-protein alleles in patients with suspected immunodeficiency. Lancet 346: 941-943.

Garred P, Harboe M, Oettinger T, Koch C, et al. (1994). Dual role of mannan-binding protein in infections: another case of heterosis? Eur. J. Immunogenet. 21: 125-131.

Garred P, Madsen HO, Balslev U, Hofmann B, et al. (1997). Susceptibility to HIV infection and progression of AIDS in relation to variant alleles of mannose-binding lectin. Lancet 349: 236-240.

Garred P, Larsen F, Seyfarth J, Fujita R, et al. (2006). Mannose-binding lectin and its genetic variants. Genes Immun. 7: 85-94.

Ghalib HW, Piuvezam MR, Skeiky YA, Siddig M, et al. (1993). Interleukin 10 production correlates with pathology in human Leishmaniadonovani infections. J. Clin. Invest. 92: 324-329.

Graudal NA, Homann C, Madsen HO, Svejgaard A, et al. (1998). Mannan binding lectin in rheumatoid arthritis. A longitudinal study. J. Rheumatol. 25: 629-635.

Hamdi S, Ejghal R, Idrissi M, Ezzikouri S, et al. (2013). A variant in the promoter of MBL2 is associated with protection against visceral leishmaniasis in Morocco. Infect. Genet. Evol. 13: 162-167.

Instituto Brasileiro de Geografia e Estatística (IBGE) (2007). Censo Demográfico. [Internet] [cited on Nov 8, 2009]. Available at [http://www.ibge.gov.br/home/estatistica/populacao/contagem2007/]. Accessed August 29, 2015.

Jeronimo SM, Duggal P, Ettinger NA, Nascimento ET, et al. (2007). Genetic predisposition to self-curing infection with the protozoan Leishmania chagasi: a genomewide scan. J. Infect. Dis. 196: 1261-1269.

Karp CL, el-Safi SH, Wynn TA, Satti MM, et al. (1993). In vivo cytokine profiles in patients with kala-azar. Marked elevation of both interleukin-10 and interferon-gamma. J. Clin. Invest. 91: 1644-1648.

Koch A, Melbye M, Sørensen P, Homøe P, et al. (2001). Acute respiratory tract infections and mannose-binding lectin insufficiency during early childhood. JAMA 285: 1316-1321.

Lau YL, Lau CS, Chan SY, Karlberg J, et al. (1996). Mannose-binding protein in Chinese patients with systemic lupus erythematosus. Arthritis Rheum. 39: 706-708.

Maia-Elkhoury AN, Alves WA, Sousa-Gomes ML, Sena JM, et al. (2008). Visceral leishmaniasis in Brazil: trends and challenges. Cad. Saude Publica 24: 2941-2947.

Nascimento Mdo D, Costa JM, Fiori BI, Viana GM, et al. (1996). The epidemiological determinant aspects in the maintenance 
of visceral leishmaniasis in the state of Maranhão, Brazil. Rev. Soc. Bras. Med. Trop. 29: 233-240.

Nylén S, Maurya R, Eidsmo L, Manandhar KD, et al. (2007). Splenic accumulation of IL-10 mRNA in T cells distinct from CD4+CD25+ (Foxp3) regulatory T cells in human visceral leishmaniasis. J. Exp. Med. 204: 805-817.

Rector A, Lemey P, Laffut W, Keyaerts E, et al. (2001). Mannan-binding lectin (MBL) gene polymorphisms in ulcerative colitis and Crohn's disease. Genes Immun. 2: 323-328.

Roy S, Knox K, Segal S, Griffiths D, et al. (2002). MBL genotype and risk of invasive pneumococcal disease: a case-control study. Lancet 359: 1569-1573.

Santos IK, Costa CH, Krieger H, Feitosa MF, et al. (2001). Mannan-binding lectin enhances susceptibility to visceral leishmaniasis. Infect. Immun. 69: 5212-5215.

Seibold F, Konrad A, Flogerzi B, Seibold-Schmid B, et al. (2004). Genetic variants of the mannan-binding lectin are associated with immune reactivity to mannans in Crohn's disease. Gastroenterology 127: 1076-1084.

Summerfield JA, Sumiya M, Levin M and Turner MW (1997). Association of mutations in mannose binding protein gene with childhood infection in consecutive hospital series. BMJ 314: 1229-1232.

Super M, Thiel S, Lu J, Levinsky RJ, et al. (1989). Association of low levels of mannan-binding protein with a common defect of opsonisation. Lancet 2: 1236-1239.

Turner MW (2003). The role of mannose-binding lectin in health and disease. Mol. Immunol. 40: 423-429.

Word Health Organization (2009). Leishmaniasis: Magnitude of the problem [Internet] [cited 2009]. Available at [http://www. who.int/leishmaniasis/burden/magnitude/burden_magnitude/en/index.html]. Accessed August 15, 2015.

Worthley DL, Bardy PG and MullighanCG (2005). Mannose-binding lectin: biology and clinical implications. Intern. Med. J. 35: 548-555. 